50 ANOS

\section{Antigos e novos sentidos da resistência}

"Resistir é preciso". O título da exposição que está percorrendo diversas capitais brasileiras remete a uma reflexão sobre o Brasil do passado e o do futuro. A mostra, organizada pelo Instituto Vladmir Herzog, traz, por meio de fotografias, cartazes e obras de arte, a história da militância da imprensa e de artistas contra a ditadura militar que, durante 21 anos, governou o país.

A exposição revive, então, uma história que completa 50 anos em 31 de março - data em que ocorreu o golpe militar que deu início à ditadura. Uma história que a mostra relata a partir da perspectiva daqueles que lutaram contra a opressão e pelo direito de expressão.

Paralelamente, 2014 é ano de eleiçôes presidenciais, o que alimenta a esperança e o sonho de um país mais democrático e igualitário. Nesse sentido, diz José Luiz del Roio, membro do Instituto Vladmir Herzog e curador adjunto da exposição, passado e futuro se comunicam. "O Brasil não é mais um país miserável, nem agrário como era na época do golpe militar. $\mathrm{Mu}$ damos muito, avançamos bastante, mas ainda falta democracia. As diversas formas de discriminação, especialmente o racismo, ainda são fortes e precisamos avançar no campo da garantia dos direitos", descreve del Roio, militante na época da ditadura e um dos fundadores da Ação Libertadora Nacional (ALN), ao lado de Carlos Mariguella.

Nesse contexto, o termo resistência, que na época da ditadura era associado à contraposição a uma ordem política vigente, renova seu significado, ganhando novos contornos como aqueles explicitados nas manifestaçôes populares que tomaram as ruas em junho de 2013, dando rosto a uma juventude até então silenciosa e tida como despolitizada. "Somos um dos países mais desiguais do planeta. A resistência ganha então um sentido de luta pela igualdade", afirma del Roio.

Luta por igualdade e por direitos sociais, reitera o sociólogo Ruy Braga, da Universidade de São Paulo (USP). "As Jornadas de Junho foram uma manifestação pela garantia e ampliação de direitos”. Direitos reivindicados por uma juventude trabalhadora e escolarizada, oriunda de camadas sociais que aumentaram seu potencial de consumo, em decorrência do forte crescimento econômico da década passada. "Mas isso não basta. Essa juventude ingressou num mercado de trabalho mais exigente e mais precário”. É, também, uma juventude que convive no cotidiano com serviços públicos de transporte, saúde e educação deficitários e falhos e que constata que uma renda melhor não assegura, necessariamente, mais qualidade de vida. "As pessoas passaram a ter dinheiro para comprar um carro, mas não conseguem pagar o seguro, a gasolina. Então continuam enfrentando o caos do transporte urbano", explica Braga, referindo-se ao mote das manifestações de junho do ano passado, o preço das tarifas dos ônibus urbanos.

Em outras palavras, a potência dos progressos alcançados, no campo da economia, do emprego, por essa nova classe média tende a se esgotar diante da persistente precariedade de acesso aos direitos sociais. Essa contradição permanece latente e, alimentada pelos questionamentos em relação à pertinência de se realizar a Copa do Mundo e pelo clima eleitoral, pode reacender os protestos e mobilizações em 2014.

A NOVA FACE DO BRASIL O jovem que foi às ruas no ano passado, contudo, não é o mesmo, por exemplo, que aquele que se travestiu de cara- pintada exigindo o impeachment do presidente Fernando Collor de Mello. Naquela época, Ruy Braga era líder estudantil e participou ativamente das manifestações. Sua experiência contribui para analisar o momento atual. "É um novo jovem e um novo Brasil que estão saindo às ruas", conclui. Um novo sujeito forjado por um contexto político, 
racteriza como blindagem do sistema político contra a influência da sociedade. Blindagem esta forjada entre as elites políticas desde o contexto do impeachment de Collor, como defesa, a fim de assegurar a manutenção das estruturas por meio de alianças entre blocos políticos, de modo a garantir a maioria - prática que se tornou comum ao longo dos governos que se sucederam desde então.

Nobre entende que a repressão policial durante os protestos foi uma expressão dessa blindagem, acirrando, naquele contexto, a reação da sociedade em busca de canais para manifestar suas insatisfações e demandas. José Luiz del Roio agrega outro elemento à análise: “Temos uma polícia treinada para matar, que não investiga, mas mata. Este é um dos muitos entulhos autoritários que carregamos da ditadura”. E a atuação dessa polícia desencadeou uma reação ainda mais intensa por parte dos manifestantes.

Há, então, um novo sujeito político em formação. Um sujeito que se movimenta ao largo das estruturas tradicionais de representação política e social, que busca inclusão e visibilidade e que forja os próprios meios - através das redes sociais, por exemplo - para expressar, canalizar sua insatisfação e promover a mobilização. "É um protagonismo mais complexo do que aquele exercido pela juventude no passado, já que aparentemente não há uma crise ou colapso. Mas há uma reivindicação por direitos sociais de uma população urbana muito sensível às situações críticas que enfrenta no dia a dia”, diz Braga, da USP.

DA RUA À POLít'ICA Se, como analisa o filósofo Marcos Nobre, em 2013 as pessoas foram às ruas pelo direito de se manifestar, pela abertura de canais entre a sociedade e o sistema político de modo que este funcione de maneira mais sintonizada com suas demandas e necessidades, existem indicações de que essa movimentação mudou o país. Mudou no sentido de que há uma nova cultura política em formação.

"O nível de mobilização alcançado em junho foi excepcional, seis milhões de pessoas foram às ruas", avalia Braga. Dificilmente, este grau se mobilização se manterá; no entanto, ele enxerga novos campos de engajamento se tecendo e conquistando espaço, como foi o caso da greve dos professores da rede municipal do Rio de Janeiro. $\mathrm{Na}$ visão dele, os professores fazem parte dos mesmos extratos sociais que ocuparam as cidades com suas reivindicações. "Pode ser que haja uma acomodação, mas ela ocorrerá num patamar muito superior ao que era”, prevê.

Em outras palavras, Braga e outros estudiosos concordam que o Brasil pós-junho de 2013 não é mais o mesmo do passado. E que não será uma surpresa se as pessoas voltarem às ruas.

O pano de fundo do cinquentenário do golpe de 31 de março de 1964 poderá alimentar a movimentação, na medida em que propõe um revisitar e uma reflexão sobre a nossa história, prevê José Luiz del Roio. A conclusão das investigaçôes sobre a causa da morte do ex-presidente João Goulart, deposto com o golpe, no âmbito da Comissão Nacional da Verdade pode trazer luzes e uma nova versão para a história do Brasil, afirma. Uma história que, na percepção de del Roio, ainda não teve seu fim.

"O processo de redemocratização ainda não está concluído. Desde 1985 estamos no regime de transição para a democracia, que ainda não está plenamente consolidada", afirma. As novas manifestações populares funcionam, então, como expressões da própria democracia em consolidação. Um processo que não pode ser desvinculado da construção de uma sociedade mais equitativa e mais justa. E isso, ainda, permanece como um desafio a ser encarado pelo Brasil.

Marta Avancini

Mais informações sobre a exposição "Resistir é preciso": http://www.resistirepreciso.org.br/ ccbb/ 